NBER WORKING PAPER SERIES

\title{
CALIFORNIA BANKING IN THE NINETEENTH CENTURY: THE ART AND METHOD OF THE BANK OF A. LEVY
}

\author{
Eugene N. White
}

Working Paper 7187

http://www.nber.org/papers/w7187

\author{
NATIONAL BUREAU OF ECONOMIC RESEARCH \\ 1050 Massachusetts Avenue \\ Cambridge, MA 02138 \\ June 1999
}

I would like to thank Charles Johnson, the librarian at the Ventura County Museum of History and Art for his invaluable assistance and Daria Lipinsky for her first-rate support as a research assistant. Helpful comments on earlier versions of this paper were received in seminars at Caltech, the NBER Summer Institute, the Conference on Banks as Firms at the Universidad Complutense (Madrid), and the XIIth International Economic History Congress. All opinions expressed are those of the authors and not those of the National Bureau of Economic Research.

(C) 1999 by Eugene N. White. All rights reserved. Short sections of text, not to exceed two paragraphs, may be quoted without explicit permission provided that full credit, including $(\mathcal{O}$ notice, is given to the source. 
California Banking in the Nineteenth Century:

The Art and Method of the Bank of A. Levy

Eugene N. White

NBER Working Paper No. 7187

June 1999

JEL No. N2, G2

\section{ABSTRACT}

An 1890s loan book of the Bank A. Levy permits a detailed examination of the lending operations of a private bank in California during the National Banking Era (1864-1914). This period has been intensively analyzed at the macroeconomic level, but there are few microeconomic studies of banks. This unregulated bank was well integrated into national money markets and lent to a broad cross section of the community. Although the bank appeared to adhere to the real bills doctrine, it provided medium term uncollateralized financing to business. The bank priced risk carefully, offering rates equal to the lowest in the country to its best customers while charging extraordinarily high rates to borrowers deemed risky. In the absence of modern accounting, close scrutiny of borrowers' businesses and personal lives overcame the asymmetry of information between borrower and lender, enabling the bank to fulfill a special intermediary role.

Eugene N. White

Department of Economics

Rutgers University

New Brunswick, NJ 08901-1248

and NBER

white@fas-econ.rutgers.edu 
Although the literature on banking in the United states during the late nineteenth century is voluminous, there is relatively little work and much speculation about the actual lending practices of banks. ${ }^{1}$ While federal and state regulators collected and reported much valuable information about commercial banks, most of their records concern aggregate balance sheets and income statements. Using this data, the empirical work of economic historians has been largely at the national and state level, not at the level of individual banks. Microeconomic studies of banking operations are rarer. Unfortunately, individual banks' documents concerning their lending activities are difficult to find or simply may not have survived.

The acquisition of the Bank of $A$. Levy, a prominent local California bank, in 1995 by First Interstate led to the deposit of its old banking records in the Ventura Country Museum of History and Art. Among the nineteenth century records preserved is one loan book. A. Levy's loan book provides an unusual window to examine the banking practices of the period. The document offers details about borrowers, interest rates, the size of loans, duration, repayments and other characteristics. This paper focuses on the lending operations of the Bank of $A$. Levy as a private bank, from its emergence in 1885 to 1905 when it obtained a state charter. Combining information from the loan book with additional data on borrowers from the U.S. Census, local business directories and voting records yields a picture of this one prominent local bank's commercial lending practices at the turn of the nineteenth century.

In contrast, there are several studies of antebellum banks. see for example, Adams (1972) and Bodenhorn (1997) and (1999), Crothers (1999) and Wright (1999). 


\section{The Origins of the Bank of A. Levy}

Many banks in the American West were founded by merchants who drifted into banking (Schweikart (1982), Doti and Schweikart (1991)). Typically, these merchants had no special expertise in banking but discovered that banking complemented and then surpassed their commercial interests. The origins and early development of the Bank of $A$. Levy follows this pattern. The bank began as a private bank or unincorporated bank. The high barriers to entry, notably the minimum capital requirements, set by the National Banking Act of 1864 and the state banking laws spurred the growth of these institutions between the Civil war and the turn of the century (James (1978), white (1983)).

on the frontier, especially in smaller communities, the general store was often the center of business life and might evolve into a private bank. Most private bankers combined some other form of business with banking. The majority of these institutions were very modest, reflecting the need to fill small niches in the financial system. After 1890, states eased entry requirements and many banned unincorporated banking, inducing or forcing many private bankers to take out a state or national charter (James, 1978). The Bank of A. Levy sought and received a state charter in 1905, reflecting both changes in state law and its own continued growth.

The founder of the Bank of A. Levy, Achille Levy, was born in Alsace to French Jewish parents in 1853. Following earlier family emigrants, he left Alsace in 1871 for California. After two years of commercial study in San Francisco, he was engaged as a clerk and bookkeeper in the store of his uncle, Isidore Weill, in solano county. In 1873, Levy moved to the port city of 
Hueneme in Ventura County. Hueneme was the only major deep water port between San Francisco and the Los Angeles port of San Pedro. It was growing rapidly, serving as the point of export for the rich agricultural county (Kramer and Stern, 1975).

By 1890, the county had a population of 10,071 , according to the U.S. Census. The predominance of men--5,881--reflects the fact that it was on the agricultural frontier. There were also a large number of immigrants, 1,861, most of whom were European. The census recorded 2185 dwellings. The 764 farms had 137,349 improved acres and 187,180 unimproved acres. In 1890, land, fences and buildings were valued at $\$ 13$ million. The estimated value of the farm products in 1889 was $\$ 1.6$ million. The predominant crop was barley, followed distantly by wheat. A scant 13 manufacturing establishments were reported with a total capital value of $\$ 368,358 .^{2}$

In Hueneme, Levy began a general merchandise business with Moise L. Wolff, a distant relative. Levy also briefly served as postmaster of the city in his store, thereby gaining a greater business acquaintance. He became a naturalized citizen in 1876 and registered to vote in 1879. Levy was elected to the town school board in 1890, served as a delegate to the County Board of Supervisors, joined the Free Masons, and was active in the local Republican Party (Kramer and Stern 1975).

In 1881, after six years of business with wolff, Levy sold out his interest to his partner, returning briefly to France to find a wife. Back in California, Levy set himself up as an agricultural broker in grain, hay, fruits, nuts and other

${ }^{2}$ Eleventh Decennial Census of the United States, 1890. Vol. I. Population, Part one, Vol. V. Report on the Statistics of Agriculture. Vol. VI. Report on Manufacturing. Part One. 
produce. When farmers brought their produce to the wharf in Hueneme, Levy was there, at the scales, to offer them the best price based on telegraphed information from the san Francisco Produce and Call Board, of which he was a member. Once a verbal agreement was struck, Levy bought the farmer's produce and paid for it with a receipt. Usually, the farmer did not collect the full sale price but left the balance with Levy. These funds could be drawn upon later to pay for supplies the farmer needed. Farmers would issue a draft or check against balances with Levy as payer (It's Been a Great Hundred Years, 1982).

Levy prospered by combining the functions of agricultural broker and banker, expanding his range of banking activities, accepting deposits and offering financial advice. He began an important business relationship, when his first customer at the bank, the manager of the huge Patterson Ranch, Charles J. Daily, deposited his life savings of $\$ 480$ on June 15, 1885. In subsequent years, Levy served as the ranch's business and financial advisor (A. LevY, 1991).

Levy's private banking operations were unregulated and his high reputation among the county's farmers bolstered this new line of business. Other Jewish merchants in the area---Moise Wolff, Abraham Bernheim and Simon Cohn---conducted private banking, but none were as successful as Achille Levy (Kramer and stern, 1975). The growth of all his businesses led Achille to hire his recently arrived brother-in-law, Henri Levy, as general bookkeeper in 1884 ( $\underline{A}$. Levy, 1991). The next year, Levy increased his independence by dissolving a partnership with wolff who paid him $\$ 57,500$ for his share.

Although his business was operating in 1885 under a sign of "A. Levy: Grain, Wool and Produce. Commission \& Forwarding," Levy 
was now a serious banker. In the first records of Levy's banking operations, April 1885-May 1886, he made loans to 90 customers. These loans were concentrated among a few prominent farmers, with four-sevenths of the loans going to 13 individuals. The $\$ 54,000$ of loans generated $\$ 1,400$ in interest earnings (A. Levy, 191). While Levy's primary banking business was with farmers, he also handled foreign exchange on all parts of Europe. His correspondent bank was the London, Paris and American Bank, Ltd. in San Francisco, owned by Lazard Frères of Paris (Kramer and Stern, 1975).

Levy was an involved banker. He sought to expand local agriculture and thereby improve his business as agricultural broker. Initially, the most important crop in the county was barley, which was shipped to Eastern breweries. However, declining barley prices threatened the prosperous agricultural community. Observing the success of lima beans, a Peruvian import, Levy began a campaign in 1888 to persuade farmers to switch from barley and hog raising to lima beans. The arrival of the Southern Pacific Railroad in 1887 made it easier to ship beans to Eastern markets, but the Hueneme wharf remained an important shipment point for crops. In 1895, 26,000 tons left the wharf, of which 60 percent were lima beans. The value of the 1895 lima bean crop was estimated to be $\$ 1.1$ million. In the mid-1890s, planting of sugar beets in the Oxnard plain began. By 1897, 1,000 acres were under cultivation, and shipments from fort Hueneme jumped (A. Levy, 1991). The following year, the oxnard Brothers built the American Beet Sugar Plant in Oxnard, which was the largest structure in the county (Kramer and Stern, 1975). Ventura County's agricultural expansion, with its demand for transportation required financing. The Bank of Ventura opened 
first in 1874, followed by the Bank of William Collins and Sons in 1887, and the Bank of Hueneme and the state Bank of Santa Paula (later the National Bank of Santa Paula) both in 1889. Later, in 1900, the Bank of Oxnard, which became the National Bank of Oxnard, was founded in 1900 with the objective of helping the sugar beat industry. ${ }^{3}$ These were modest financial intermediaries. In 1896, there were 31 national banks in California, with $\$ 21.6$ million in assets. The largest, the First National Bank, San Francisco had $\$ 7.1$ million in assets, compared to the $\$ 184,415$ of assets held by the First National Bank of Santa Paula, the state's fourth smallest national bank (U.S. Comptroller of the Currency, 1896).

While his own banking business was developing, A. Levy had joined with several other businessmen, including Senator Thomas Bard, to found the Bank of Hueneme, which had an initial capital of $\$ 100,000$. Levy was elected Vice President and bought $\$ 5000$ of stock. As an officer of the Bank of Hueneme, Levy was able to further his own brokerage and banking business, obtaining overdrafts from the Bank when required. By 1895, Levy established himself as the premier local private banker, with a bank under his name in a Main street building between the mercantile store of Lehmann and waterman and the leading hotel (A. Levy, 1991). The Ventura Free Press (December 1895) commented: "His reputation for square dealing is as wide as the county and there is no businessman more popular among the farmers." Levy was now better known as a banker than a broker. In 1901 he bought a lot in the town of oxnard, inland from Hueneme, where he built a brick building for his bank. Completed in 1902 it served as the bank's

\footnotetext{
3 The Bank of William Collins and Sons failed, having overextended its mortgage loans. Fairbanks, (1963), pp. 3-7.
} 
office for the next quarter century.

In 1905, the bank was incorporated as a state regulated bank with a capital of $\$ 200,000$ and Levy as President. Intending to keep ownership local and in his hands, Achille Levy and his wife Lucy purchased 1,088 of the 2,000 shares for $\$ 108,800$. Other relations, provided another $\$ 28,000$ of the capital and non-family members, the remainder. Eventually, the Bank of A. Levy became the largest bank in the county, until Bank of Italy, forerunner of the Bank of America planted a branch in the county in the $1920 \mathrm{~s}$. When Levy died in 1922, he was the wealthiest individual in the county and paid the most income tax (Kramer and stern (1975), A. Levy (1991), "A. Levy, Country Pioneer is Called" (1922)).

The regulatory environment in which the Bank of $A$. Levy operated between 1885 and 1905 was light for chartered banks and virtually non-existent for private banks like Levy's. Among Western states, California was one of the earliest to adopt general banking laws. In 1878, the state legislature required banks to publish information about their financial condition and established a Board of Bank Commissioners. Commissioners examined each bank twice yearly until 1905 but complained that the legislature ignored its reports and recommendations. "The first time, the commissioners finally managed to inspect all 127 incorporated commercial and savings banks in 1888, they warned about the dangerous practices they had discovered. The Board wanted to examine the unincorporated banks, yet it had no power to do so (Doti and Schweikart, 1994). Thus, A. Levy's bank was

\footnotetext{
${ }^{4}$ One contemporary Ventura bank officer remembered that the commissioners were " all political appointments, men without
banking experience, and many of them could not even balance the
cash," Fairbanks, (1963), p. 6 .
} 
for all purposes, an unregulated, unexamined and unsupervised bank until 1905 .

\section{Bank Lending}

Among the extant bank records in the Ventura County Museum is one loan book, "Notes and Bills Receivable." While other studies of late nineteenth century banking have depended on aggregate data reported to bank regulators, this document provides an opportunity for a true microeconomic examination of bank lending. The loan book records the 330 loans made or obtained by Achille Levy from August 8, 1892 (loan 790) to october 11, 1894 (loan 1119). Most of the loans were originated and held by Levy; only 22 loans were purchased from other lenders. The loan book records the name of the borrower, the sum borrowed, the interest rate, the duration of the loan, the date repaid, plus notes.

In the loan book, the borrower or "drawer" signed a bill or note "in favor of" the "payee" who was Achille Levy, the banker. These "bills" were not resold but were held until payment by Levy. The loans were, in effect, unsecured promissory notes. T. Russell Carroll, first bookkeeper and finally vice president of the bank, described Levy as a disciple of the "character loan" method. If he determined that an applicant was of good character, Levy was willing to lend large sums with no collateral. But, if he decided that a potential borrower's character was flawed, no loan would be offered no matter what the collateral. According to carroll, this character method helped to ensure that Levy experienced few losses (Carroll (1958), A. Levy (1991)). On his visits to farmers, Levy carried a pocketsized notebook where he recorded his daily activities and 
indications of farmers' credit-worthiness. Unfortunately, the absence of deposit records in the bank does not allow the linkage of lending to any monitoring of borrowers by the activity of their depository records. Furthermore, without these records it cannot be determined whether borrower carried any compensatory balances that may have altered the effective interest rate charged to a borrower.

The character loan approach to lending was fairly typical of country bankers' practices. Albert $S$. Bolles (1884), one contemporary banking authority, found that country bankers often did not ask for collateral but based their loans on their long acquaintance with customers. An intimate personal knowledge of the borrower's business and personal character was necessary in the absence of reliable financial statements. Accountants had little authority to impose standardized accounting procedures on clients and there were few statutory requirements for accounting in this period. To compensate for the asymmetry of formal information between borrower and lender, bankers needed close personal ties. Only when financial accounting began to develop did a few urban banks begin in the $1890 \mathrm{~s}$ to use financial statements to evaluate borrowers (Moulton (1918), Brief (1966), White (1998)).

Much of modern banking theory (Battacharya and Thakor (1993), White (1998)) builds on the asymmetry of information between borrowers and lenders. Investing in the acquisition of information on their customers allows banks to provide credit to new borrowers, poor credit risks and even established borrowers who want to signal creditworthiness to the market. This distinctive function is often heralded as the "special" characteristic of banking. The Bank of A. Levy was a special 
lender in this sense. Some of its customers might have sold a promissory note to another local resident, but none could have entered the national commercial paper market, leaving them dependent on bank for most of their financial needs.

The loans of the Bank of $A$. Levy were typical of many small banks. The total value of the 330 loans granted in the loan book was $\$ 124,120.34$. Although the average size loan was $\$ 376$, there was considerable variation in the size of the loans offered.

Figure 1 shows the size distribution of loans, which ranged from $\$ 5$ to $\$ 5244$ with a mode of $\$ 21$ to $\$ 100$. The relatively modest size of these loans was similar to other small banks. The Comptroller of the Currency (1880) reported that the average size loan for country national banks in the Western and Midwestern states was $\$ 713$.

Almost all nineteenth century banking theorists concurred that bank loans should be structured to meet the dictates of the real bills doctrine. This theory held that banks should take only short-term loans to finance the production or shipment of goods, whose final sale would be used to pay off the loan. The bill of exchange was usually regarded as the appropriate and safe instrument for this form of intermediation. Proponents of the real bills doctrine claimed that if banks followed its prescription, loans would be restricted to the legitimate needs of business, and banks would remain liquid. ${ }^{5}$ Short-term loans, promptly paid at maturity would reduce the problem of a maturity mismatch with deposits and limit a bank's exposure to panic. Yet, the Bank of A. Levy's loans did not follow the prescription of

s In this period, liquidity meant that an asset would be immediately paid off at maturity, not that it was easy to market. White (1998). 
the real bills doctrine. The loans were not double name but single name paper. ${ }^{6}$ No protection was offered by a second name, nor was there any collateral.

Figure 1

Size Distribution of Loans (330 Loans)

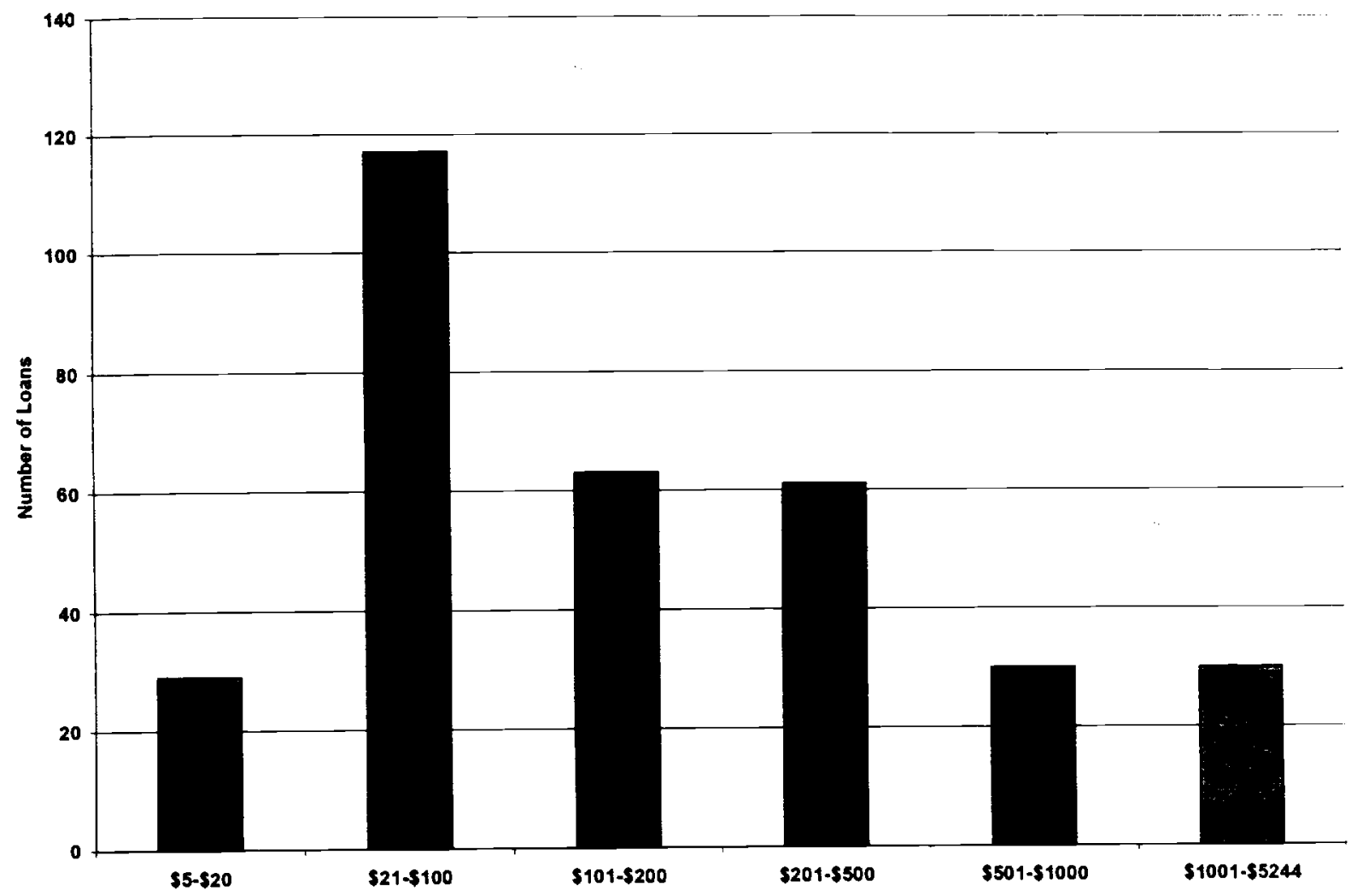

But the loans did follow the spirit of the real bills doctrine in that they were nominally short term loans. The vast majority--283 loans---were one day loans. The initial loan maturities are shown in Figure 2. Some time loans, with maturities as long as a year or more were given, but the banker's

${ }^{6}$ It is interesting to note that Pacific and Western banks had a high percentage of single to double name paper (James, 1978), p. 59 . 
clear preference was for one day loans. The one day loan made the bank appear to be nominally quite liquid, as in theory Levy could call the loans for repayment at one day's notice. These loan maturities closely matched the initial maturities of $A$. Levy's borrowed funds. One "Notes and Bilis Payable" book for September 26, 1894 (BilI No. 47) to september 1, 1904 (Bill No. 195a) is also held by the Ventura County Museum. Almost all were nominally one-day loans. Levy's correspondent bank supplied most of these funds, with occasional borrowing from the Bank of Hueneme and other private banks.

\section{Figure 2}

Initial Loan Maturities (330 Loans)

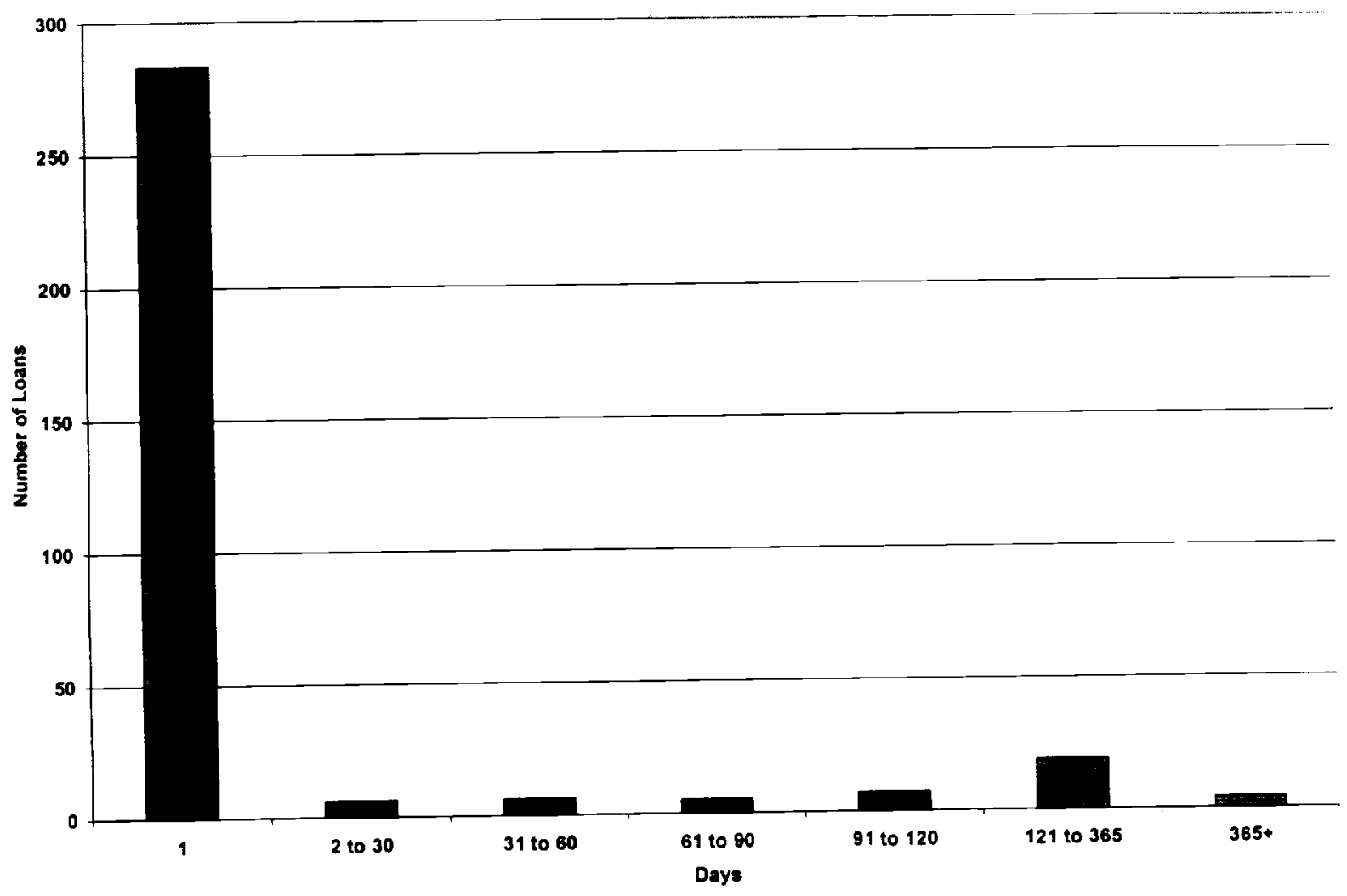


Figure 3

Actual Duration of Loans (317 Loans)

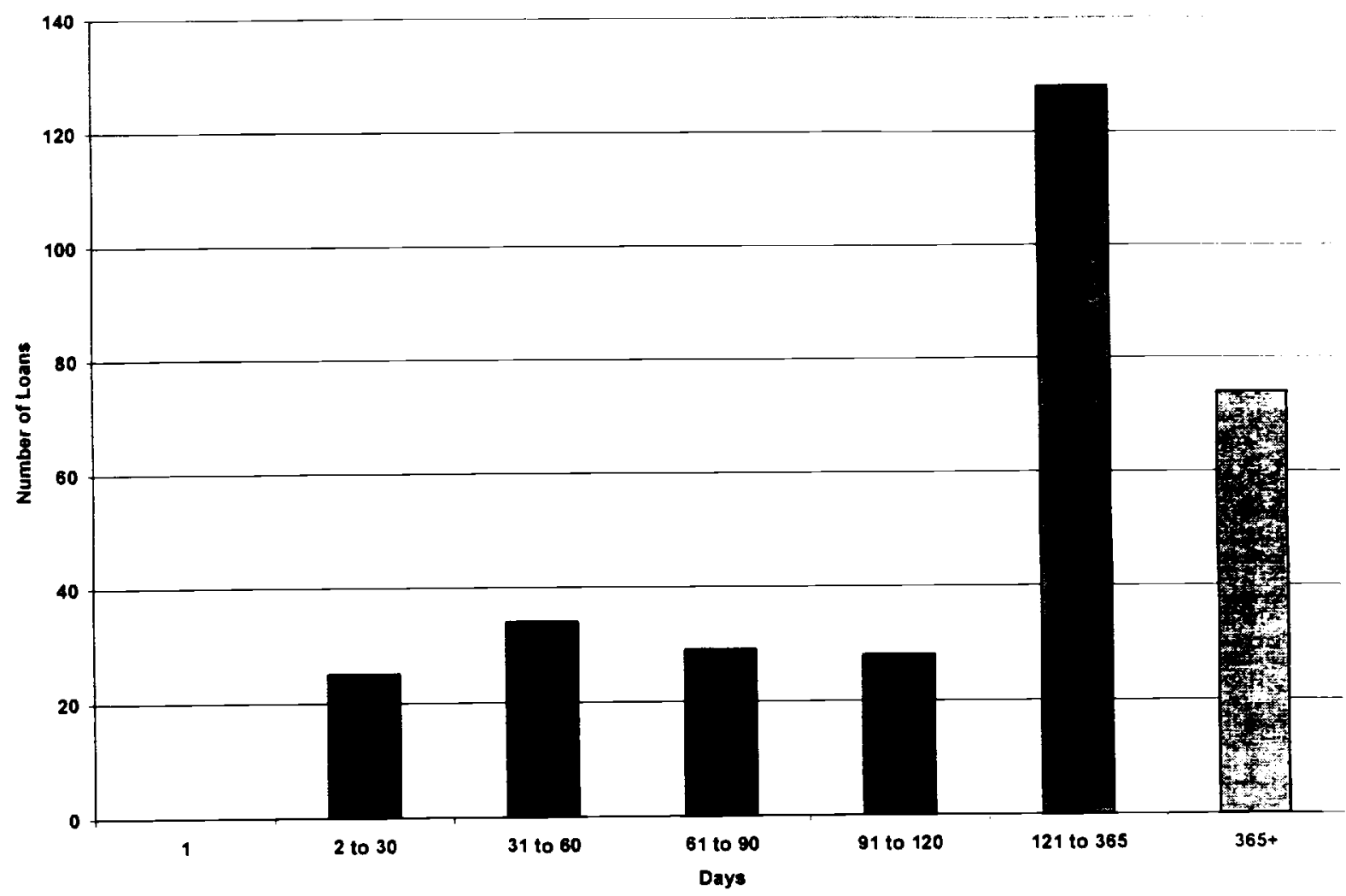

However, this near match of maturity was an illusion. Levy's loans seem to have been automatically rolled over and there is no evidence in the loan book that any were called before the borrower was ready to repay the debt. It appears that the automatic rolling over of a loan was understood as the payment period for most one day loans was set at one percent per quarter. Figure 3 shows the actual duration for 317 loans. There were 13 loans for which it was not possible to determine when the loan was repaid. The average duration of a loan was 279 days or about nine months.' The modal range in Figure 3 is between four months

${ }^{7}$ The average actual term of Levy's borrowed funds was 199 days in 1895 . 
and one year. There was very little amortization of the loans made by the Bank of $A$. Levy. On all but 31 of the loans, the principal was paid off in its entirety at the end of the loan. For a few loans some irregular payment on the principal was made before the loan was concluded.

The actual maturities on A. Levy's loans appear to have been quite long by standards of the period. According to most contemporary banking authorities, most loans at the turn of the nineteenth century ran for 30,60 or 90 days, although they were certainly considering nominal not actual maturities. In a 1913 study, the Comptroller of the Currency found that 57 percent of all bank loans were made with maturities of less than ninety days. John James (1978) concluded that it was relatively rare to see loans longer than six months and one year seemed to be the upper bound. He believed the average maturity to be 60 days. Yet, it was widely known that many commercial loans, maybe 40 to 50 percent of unsecured loans in large cities, were renewed at maturity (Moulton, 1918). Some limited evidence on country bank practices suggests that agricultural loans typically ran for three to nine months (James, 1978). The Bank of A. Levy's practices may thus have been in line with standard commercial practice. Being unregulated it did not feel obliged to conceal the fact that it ignored the real bills doctrine and made longterm uncollateralized loans.

The interest rates charged on the loans varied enormously. As seen in Figure 4, which reports the interest rate frequencies for 305 loans, the annual interest rate for 197 loans was 4 percent. ${ }^{8}$ Twenty loans bore 5 percent and 33 loans 6 percent.

${ }^{8}$ For 21 mostly purchased loans, the rate of interest was not possible to calculate with the information in the loan book. 
Under California law, there was no usury rate, and a surprising 39 loans were charged 40 percent (Holmes and Lord, 1895). "The average rate for the whole portfolio was 7.32 percent, a consequence of the fact that one tenth of the loans carried the 40 percent rate.

Figure 4

Annual Interest Rates Charged (305 Loans)

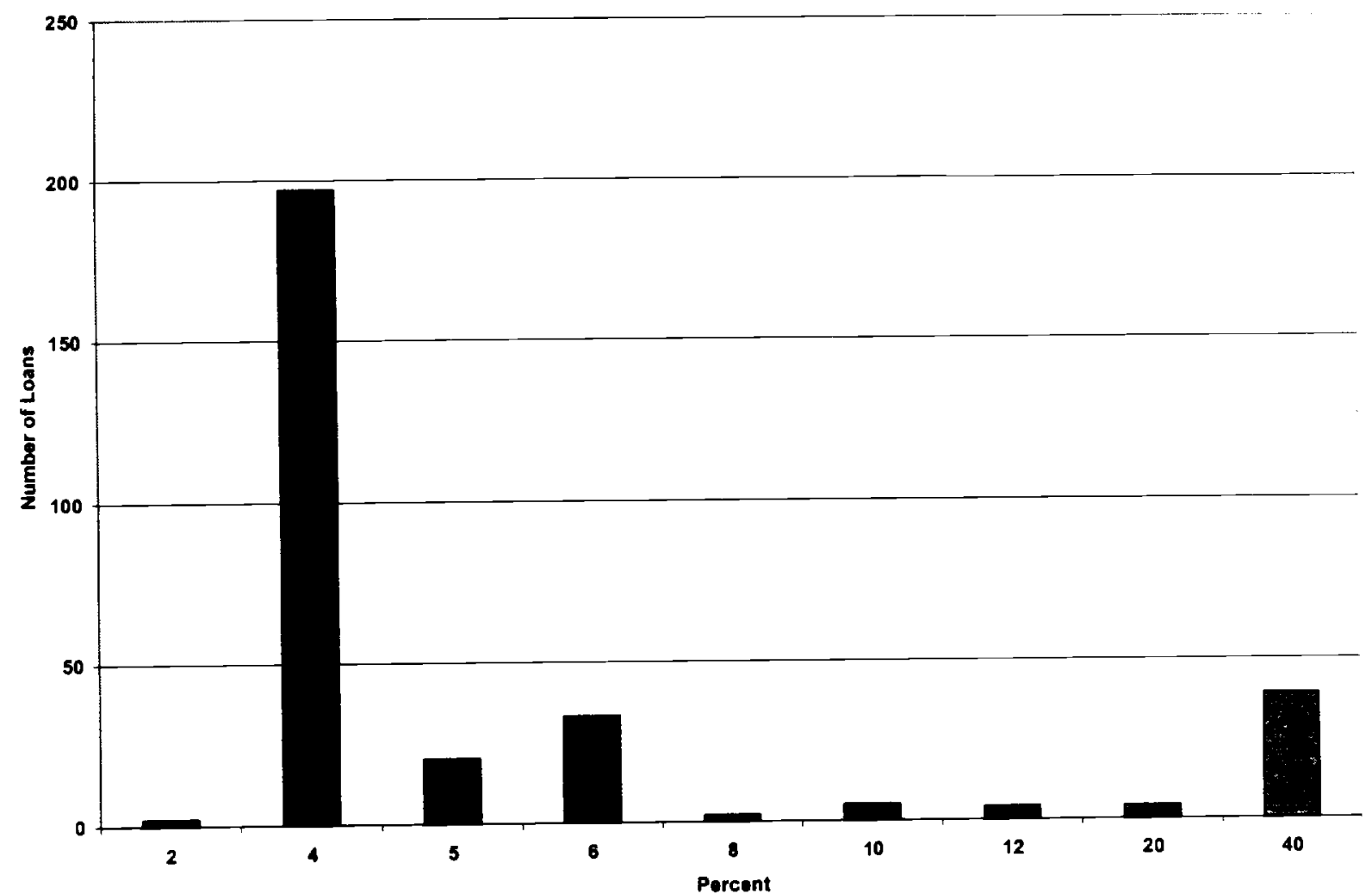

Cautious as Achille Levy might be, he still sustained some losses from his loans. ${ }^{10}$ Seven loans produced losses that had to be absorbed by the bank, being "charged to P\&L." These loans

${ }^{9}$ Holmes and Lord, (1895), p. 170.

${ }^{10}$ For five loans it was not possible to determine if the loans had been paid off. 
represented a total loss of $\$ 2,742$. Losses on the loans ranged from a high of $\$ 1640$ to $\$ 74$. The rates charged at the outset seemed no guide as five loans were at 4 percent, one was at 6 percent and one was at 40 percent. Another seven loans were charged to the borrowers' deposit accounts when they failed to repay their debts. These loans totaled $\$ 2655$, with the largest loan being $\$ 2120$. In addition, there was one loan for $\$ 30.50$ that was apparently granted free of interest.

\section{Money Market Integration}

In nineteenth century America, there was considerable variation in short-term regional interest rates. $R$. $M$. Breckenridge (1898) compiled the average weekly rates of discount from selected cities, for 1893-1897, as reported in Bradstreet's. These rates were supposed to represent the local discount rate on loans of high quality prime, double-name paper. Rates in the New England cities averaged 4.9 percent, 4.9 percent in the East, 7.3 percent in the South, 6.4 in the Midwest, 9.0 percent in the West, and 8.6 in the Pacific states. The average rate was 6.2 percent in San Francisco and 7.1 percent in Los Angeles. While A. Levy's average of 7.32 percent certainly "fits" this region, it is somewhat misleading because the standard rate for loans was clearly 4 percent.

The high rates for the Pacific region are a common finding. In his seminal paper, Lance Davis (1965) found a substantial interest rate premium persisted for the west coast as late as the 1890s, with a proxy for interest rates, well above 8 percent for that decade. John James (1978) computed regional interest rates to study interest rate differentials. For the west during the period which A. Levy's book covers, James' semi-annual rates 
were 1892 II: $8.1,1893$ I: 8.8, 1893 II: 7.3, 1894 I: 5.8, 1894 II: 7.4 percent. Interestingly, the modal rates charged by $A$. Levy are closer to the average rates for the East, around 4 percent for these years. Most recently, Howard Bodenhorn (1995) provided alternative regional interest rate estimates. For the West, his weighted rates were 1892: 9.24, 1893: 11.42, and 1894: 9.44 percent.

These rates, which are estimates not actual interest rates, seem remarkably high compared to most of the actual rates reported by Achille Levy. To offer a better comparison of Levy's rates with the estimates produced by Davis, James, and Bodenhorn, I used their procedure for estimating the interest rate on the Bank of A. Levy data. For the 305 loans where there is complete data, I calculated the interest revenue on each loan (the value of the loan times the yearly interest rate times the fraction of years the loan was outstanding--a total of $\$ 21,775$ ) and subtracted the loan losses. The estimated interest rate on loans was then obtained by dividing the resulting figure by the value of the loans. The estimated rate of interest from this procedure was 15.3 percent. This very high figure fits into the picture drawn by Davis, James and Bodenhorn. One would expect that a rural county between the financial centers of Los Angeles and San Francisco would have higher rates than the state or regional average. However, this high number is the result of a relatively small number of borrowers paying interest as high as 40 percent, when the large majority paid as low as four percent. What Levy's loan book suggests is that the risky borrowers had to pay penalty rates for credit. Their interest payments are what boosted interest earnings and the apparently high estimated interest rate. Was ventura county not well integrated into financial 
markets? Most of Levy's borrowers found credit available at 4 percent. For these individuals, the market supplied loans at nationally low rates--rates close to the estimated rates for New England and the Northeast.

Levy apparently could tap into the regional market for funds through his correspondent bank. He made frequent use of the market to fund his lending operations. One indication is the "Bills and Notes Payable" for 1895. In this year, Levy borrowed a total of $\$ 40,255$ in 36 loans, all but four of which were at 6 percent. Given an average term of 199 days, Levy's average outstanding borrowing in 1895 was $\$ 26,420$. The average value of loans outstanding per year for 1892-1894 was approximately $\$ 47,000$, after adjusting for maturity. Thus, Levy seems to have funded over half of his lending with borrowed funds. The actual interest cost of those funds was $\$ 1661$. If this were the actual cost of all funds (it is not for the same time period), the total cost would be $\$ 2225$. The average annual earnings for 1892-1894 were $\$ 8318$, implying an approximate rate of return of nearly 13 percent.

\section{The Pricing of Loans}

As an alleged disciple of character loans, Levy would have set loan rates with a knowledge of the risks presented by his customers. There is no indication of risk in the loan book and Levy's pocket notebooks do not appear to have survived. To recover some information on how Levy set loan rates, an econometric analysis of the loans using data from the loan book, the census, and other sources was carried out.

The cost of funds might have influenced the loan rates. Thus, the current and one month lagged New York commercial paper 
rates were included in the regressions. ${ }^{11}$ The term of the loan may have been another consideration. The initial or nominal maturity first entered in the loan book was used. Steady customers were measured by the number of times an individual had previously borrowed. The dollar value of the loan or the dollar value of all loans a borrower had outstanding could have influenced the loan rate. Multiple borrowers may have provided additional protection for repayment of the loan. Levy purchased some loans and this fact was included. The age of the borrower and whether the borrower was identified by his or her surname as Mexican were included as possible factors. Additional sources, notably the 1900 manuscript federal census for Ventura county provided information on whether an individual owned or rented property, had a mortgage, was native or foreign born, or was married.

Table 1 reports the results of the oLs regressions. Characterizing the dependent variable, the interest rate, as a continuous variable is not quite appropriate, as there were only nine values. It is also not practical to model the determination of the interest rate as an ordered probit, given the number of rates. Instead, interest rates were grouped as low and high risk. Rates were "high" if they exceeded 7 percent and "low" if they fell below 7 percent, yielding a 1 or a 0 for the dependent variable for the probits reported in Table 2 . In both tables, regressions 1 and 2 used the full sample for which loan rates were available, with either the dollar value of the specific loan or the value of all loans outstanding. These were not used in the same regression as they were highly correlated.

${ }^{11}$ Banking and Monetary Statistics, (1943), Table No. 120, p. 448. 
The third and fourth regressions include the additional variables, for which there were fewer observations.

Table 1

The Determination of Loan Rates OLS Estimates

\begin{tabular}{|c|c|c|c|c|}
\hline & (1) & (2) & (3) & (4) \\
\hline Constant & $\begin{array}{r}0.122 \\
(4.01)\end{array}$ & $\begin{array}{r}0.121 \\
(3.98)\end{array}$ & $\begin{array}{r}0.176 \\
(1.57)\end{array}$ & $\begin{array}{r}0.142 \\
(1.356)\end{array}$ \\
\hline Commercial Paper Rate (t) & $\begin{array}{l}0.374 \\
(0.48)\end{array}$ & $\begin{array}{l}0.387 \\
(0.51)\end{array}$ & $\begin{array}{l}2.811 \\
(1.71)\end{array}$ & $\begin{array}{l}2.601 \\
(1.59)\end{array}$ \\
\hline Commercial Paper Rate $(t-1)$ & $\begin{array}{l}-0.865 \\
(-1.06)\end{array}$ & $\begin{array}{l}-0.834 \\
(-1.03)\end{array}$ & $\begin{array}{l}-2.576 \\
(-1.51)\end{array}$ & $\begin{array}{l}-2.459 \\
(-1.43)\end{array}$ \\
\hline Initial Maturity (days) & $\begin{array}{r}0.00003 \\
(0.51)\end{array}$ & $\begin{array}{r}0.000005 \\
(0.09)\end{array}$ & $\begin{array}{r}-0.00006 \\
(-0.64)\end{array}$ & $\begin{array}{r}-0.00006 \\
(-0.72)\end{array}$ \\
\hline Times previously Borrowed & $\begin{array}{l}-0.011 \\
(-2.41)\end{array}$ & $\begin{array}{l}-0.015 \\
(-3.38)\end{array}$ & $\begin{array}{r}-0.018 \\
(-1.89)\end{array}$ & $\begin{array}{l}-0.018 \\
(-1.94)\end{array}$ \\
\hline Dollar Value of Loan & $\begin{array}{r}0.00004 \\
(3.87)\end{array}$ & & $\begin{array}{l}0.0001 \\
(3.91)\end{array}$ & $\begin{array}{l}0.0001 \\
(4.15)\end{array}$ \\
\hline Value of Loans Outstanding & & $\begin{array}{r}0.00004 \\
(4.33)\end{array}$ & & \\
\hline Multiple Borrowers & $\begin{array}{l}-0.0009 \\
(-0.05)\end{array}$ & $\begin{array}{l}-0.0009 \\
(-0.05)\end{array}$ & $\begin{array}{l}0.028 \\
(0.7)\end{array}$ & $\begin{array}{l}0.029 \\
(0.72)\end{array}$ \\
\hline Purchased Loan & $\begin{array}{l}0.009 \\
(0.26)\end{array}$ & $\begin{array}{c}0.019 \\
(0.49)\end{array}$ & $\begin{array}{l}-0.075 \\
(-0.77)\end{array}$ & $\begin{array}{r}-0.09 \\
(-0.92)\end{array}$ \\
\hline Mexican Borrower & $\begin{array}{l}-0.024 \\
(-1.17)\end{array}$ & $\begin{array}{l}-0.024 \\
(-1.17)\end{array}$ & & \\
\hline Age of Borrower & & & $\begin{array}{l}-0.001 \\
(-0.86)\end{array}$ & $\begin{array}{l}-0.001 \\
(-0.59)\end{array}$ \\
\hline Farm & & & $\begin{array}{l}-0.066 \\
(-1.58)\end{array}$ & $\begin{array}{l}-0.062 \\
(-1.36)\end{array}$ \\
\hline Rent & & & $\begin{array}{r}-0.025 \\
(-0.818)\end{array}$ & \\
\hline Mortgage & & & & $\begin{array}{l}-0.002 \\
(-0.05)\end{array}$ \\
\hline Foreign Born & & & $\begin{array}{l}-0.011 \\
(-0.38)\end{array}$ & $\begin{array}{l}-0.017 \\
(-0.57)\end{array}$ \\
\hline Married & & & $\begin{array}{c}0.041 \\
(1.01)\end{array}$ & $\begin{array}{c}0.049 \\
(1.16)\end{array}$ \\
\hline Number of observations & 305 & 305 & 96 & 96 \\
\hline Adjusted R2 & 0.07 & 0.08 & 0.17 & 0.16 \\
\hline F-statistic & 3.876 & 4.376 & 2.603 & 2.527 \\
\hline
\end{tabular}

The numbers in parentheses are t-statistics. 
Table 2

The Determinants of Loan Rates

Probit Estimates

\begin{tabular}{|c|c|c|c|c|}
\hline & (1) & (2) & (3) & (4) \\
\hline Constant & $\begin{array}{l}-0.032 \\
(-0.06)\end{array}$ & $\begin{array}{r}0.025 \\
(0.05)\end{array}$ & $\begin{array}{r}0.933 \\
(0.56)\end{array}$ & $\begin{array}{r}0.413 \\
(0.27)\end{array}$ \\
\hline Commercial Paper Rate (t) & $\begin{array}{l}-7.602 \\
(-0.66)\end{array}$ & $\begin{array}{l}-9.996 \\
(-0.86)\end{array}$ & $\begin{array}{l}34.442 \\
(1.32)\end{array}$ & $\begin{array}{l}31.043 \\
11.21 ;\end{array}$ \\
\hline Commercial Paper Rate $(t-1)$ & $\begin{array}{l}-7.141 \\
(-0.58)\end{array}$ & $\begin{array}{l}-4.639 \\
(-0.38)\end{array}$ & $\begin{array}{r}-38.49 \\
(-1.299)\end{array}$ & $\begin{array}{l}-35.539 \\
(-1.206)\end{array}$ \\
\hline Initial Maturity (days) & $\begin{array}{r}0.001 \\
(1.77)\end{array}$ & $\begin{array}{r}0.001 \\
(1.48)\end{array}$ & $\begin{array}{r}0.003 \\
(1.16)\end{array}$ & $\begin{array}{l}0.003 \\
(1 . \pm 8)\end{array}$ \\
\hline Times Previously Borrowed & $\begin{array}{l}-0.398 \\
(-3.85)\end{array}$ & $\begin{array}{l}-0.446 \\
(-4.39)\end{array}$ & $\begin{array}{l}-0.634 \\
(-2.57)\end{array}$ & $\begin{array}{l}-.0644 \\
(-2.65)\end{array}$ \\
\hline Dollar Value of Loan & $\begin{array}{l}0.0007 \\
(3.91)\end{array}$ & & $\begin{array}{r}0.001 \\
(3.05)\end{array}$ & $\begin{array}{r}0.002 \\
(3.18)\end{array}$ \\
\hline Value of Loans Outstanding & & $\begin{array}{l}0.0005 \\
(3.86)\end{array}$ & & \\
\hline Multiple Borrowers & $\begin{array}{l}-0.113 \\
(-0.38)\end{array}$ & $\begin{array}{l}-0.143 \\
(-0.48)\end{array}$ & $\begin{array}{r}0.428 \\
(0.76)\end{array}$ & $\begin{array}{l}0.466 \\
(0.84)\end{array}$ \\
\hline Purchased Loan & $\begin{array}{r}1.088 \\
(2.01)\end{array}$ & $\begin{array}{r}1.131 \\
(2.08)\end{array}$ & $\begin{array}{r}-0.467 \\
(-0.31)\end{array}$ & $\begin{array}{l}-0.674 \\
(-0.45)\end{array}$ \\
\hline Mexican Borrower & $\begin{array}{l}-0.397 \\
(-1.13)\end{array}$ & $\begin{array}{l}-0.456 \\
(-1.26)\end{array}$ & & \\
\hline Age of Borrower & & & $\begin{array}{r}-0.032 \\
(-1.445)\end{array}$ & $\begin{array}{l}-0.025 \\
(-1.19)\end{array}$ \\
\hline Farm & & & $\begin{array}{r}-0.496 \\
(-1.001)\end{array}$ & $\begin{array}{r}-0.559 \\
(-1.023)\end{array}$ \\
\hline Rent & & & $\begin{array}{r}-0.444 \\
(-1.048)\end{array}$ & \\
\hline Mortgage & & & & $\begin{array}{l}0.135 \\
(0.31)\end{array}$ \\
\hline Foreign Born & & & $\begin{array}{r}-0.198 \\
(0.49)\end{array}$ & $\begin{array}{r}-0.22 \\
(-0.54)\end{array}$ \\
\hline Married & & & $\begin{array}{r}0.412 \\
(0.67)\end{array}$ & $\begin{array}{r}0.54 \\
(0.80)\end{array}$ \\
\hline Number of Observations & 305 & 305 & 96 & 96 \\
\hline Log Likelihood & -112.4 & -112.8 & -32.5 & $-32 \cdot 9$ \\
\hline
\end{tabular}

The number in parentheses are approximate t-statistics. 
In all four regressions, the varying costs of the money market, which moved considerably in this period from 4.94 to 10.14 percent, had no influence on the loan rates. This result is perhaps not surprising as Levy seems to have held his base loan rate constant at 4 percent for two years and his cost of funds for 1895 remained constant at 6 percent. The initial maturity of the loan had little apparent effect on the rate charged in the oLs regression, but the probit estimates are a bit sharper. In Table 2's regressions 1 and 2 , the coefficients suggest that a higher initial maturity raised rates, implying a positive yield curve.

One indication of reputation, the number of times an individual had previously borrowed was an important variable, reducing the loan rate significantly. Another important variable was the size of the loan, measured either by the individual loan or all outstanding loans to one borrower. The larger the value of the loan(s) outstanding, the higher the rate charged.

Contrary to the claim that a borrower with good character could costlessly increase his or her credit, the oLs regression suggests that every additional $\$ 1000$ raised the rate by one tenth of a percent. Multiple signatories to the loan, whether it was purchased or whether it was repaid had no apparent effect on the loan rate. The age of the borrower appears to have had some effect in lowering the cost of the loan. Age may be a proxy for some measure of reputation or wealth. None of the other factors, farm ownership, renting, foreign born or married, helped to explain the variation in loan rates.

While these regressions offer some evidence that reputation, measured by repeated borrowing or age, and risk, in terms of the size of the loan, influence the loan rate, they do not yield much 
insight into the risks that A. Levy observed. Ten percent a quarter or 40 percent a year was Levy's rate for risks, and it was used for many different occasions. Some one time borrowers were charged 40 percent. Pedro Chanchorena, M. Kujawsky, and George C. Smith were all charged 40 percent for their initial loans; but once they repaid, their subsequent rates dropped to 4 or 5 percent. A sudden increase in borrowing needs could drive the rate for an individual up. William Reilly was charged 4 percent on his first loan of $\$ 125,40$ percent on the second loan of $\$ 1600$, and finally 4 percent again on the third loan of $\$ 275$. John Glinchy had borrowed five times at 4 percent on small loans but his final loan of $\$ 1000$ gave him a rate of 40 percent, perhaps as his risk increased. Finally, there were customers like Julius Alvord whose four loans totaling $\$ 2787$ all bore the same 40 percent rate. The regressions do note easily pick up the factors leading Achille Levy's shifts in rates from 4 to 40 or 40 to 4 percent, but one may surmise that changes in risk drove these adjustments.

\section{Who Borrowed?}

Studying early nineteenth century New England banks, Naomi Lamoreaux (1994) found that many were founded with the purpose of financially assisting the bank owners' and directors' business operations. Providing a circle of credit, insider lending was pervasive, and only in the later part of the century did banking slowly become more professional and begin to eliminate what today would be considered conflicts of interest. While A. Levy was operated on a frontier with many closely intersecting business interests, he provided most of the capital for the bank in its early years and insider lending of the New England variety was 
not an issue. The loan book has no recorded loan to any member of the extended Levy family for the years 1892-1894. Only Achille Levy's former business partner, Moise Wolff, obtained a relatively small loan. In fact, some small loans were given to Levy's rival brokers. Lending appears to have gone to creditworthy customers, mostly large and some small.

In the nearly two year period that this loan book covers, Levy made 330 loans to a total of 176 borrowers. However, many clients borrowed repeatedly. There were 71 borrowers who borrowed more than once during this period. Their loans represented the lion's share--\$86,270 of the $\$ 124,120$ loans that Levy made. Figure 5 shows the number of borrowers who had anywhere from two to eight loans, while Figure 6 shows the dollar value of the multiple loans. Levy was clearly providing continuous financing of many farmers in ventura county. Some, like the Donlon Brothers or Bicente Duralde, received substantial credits, totaling $\$ 4685$ (4 loans) and $\$ 3016$ (5 loans) respectively. For others, there was modest but sustained credit. In five loans, John Grainger obtained a total of $\$ 500$; and Christopher Robinson $\$ 75$. These loans often overlapped, again. suggesting that Levy gave continuous financing to his customers. 
Figure 5

Number of Borrowers Receiving Multiple Loans

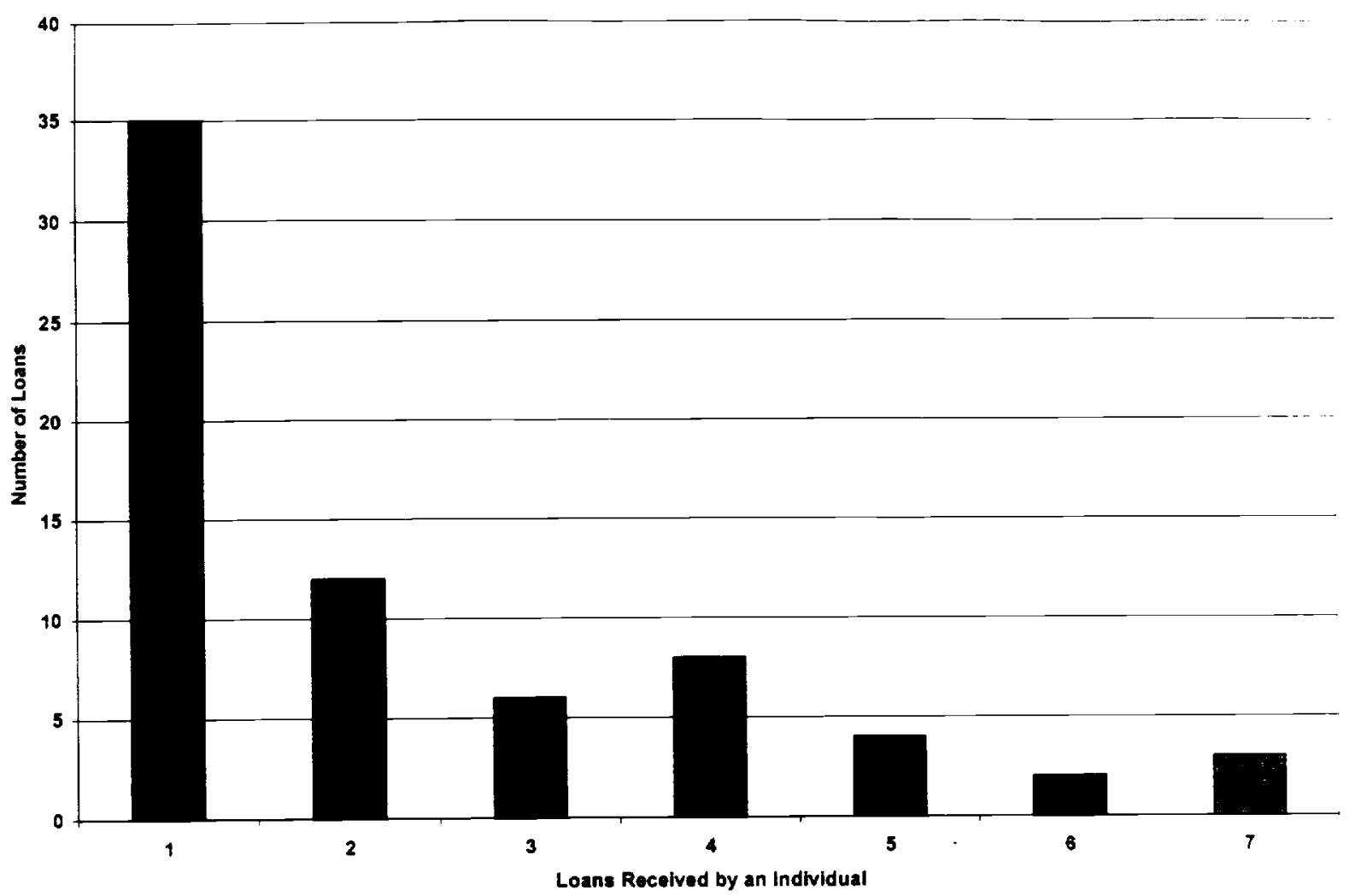

While his borrowers were certainly not a cross section of Ventura County, they were a diverse group. Levy did not record personal information on any of his borrowers, however some idea of who they were was obtained by matching the borrowers with the 1900 Census for Ventura County. Although there were one or two exceptions all the borrowers were men, and according to the Census of 1900, all those who were matched were literate. For occupations, there were 89 matches, which reveal that Levy's clientele was predominantly the farming community. Sixty-nine were farmers, three were brokers or merchants, and two were stock farmers. For the remainder there was one carpenter, bartender, owner of a farmers' market, foreman, insurance agent, laundryman, lighthouse keeper/inventor, notary/real estate agent, restaurant 
owner, teacher, sheep herder and watchman.

Figure 6

Value of Multiple Loans

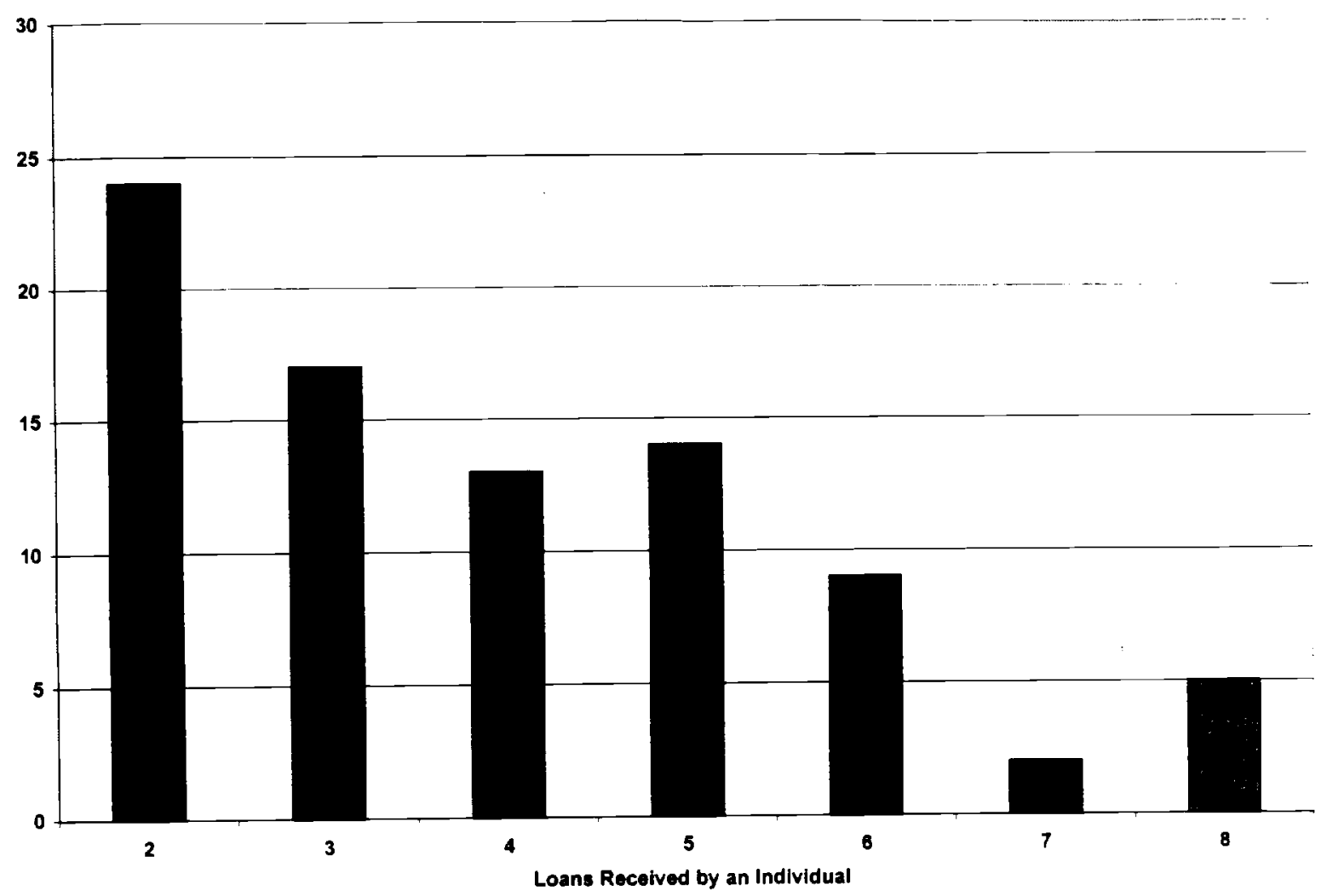

The matches with the 1900 manuscript census give some information about their ownership of property. Fifty-four had farms, of which ten were owned outright, twenty-one were mortgaged and the remainder were rented. There were an additional thirteen homeowners, seven of whom owned their property outright, two had mortgages and three rented.

The bank's clientele was surprisingly young. Most of the men, forty-six, were in their twenties with another thirty in their thirties. It is difficult to compare this youtheul group with the population of the county as a whole. However, it may well have been representative. The 1890 Census of Population for 
Ventura County records 77 percent of the white male population between the ages of 18 and 44 .

While Achille Levy certainly gave loans out to his business friends, his clientele included many beyond his personal circle as indicated by the loans to his Hispanic clients. Eleven borrowers with Spanish surnames took out 38 loans, totaling $\$ 20,423 .{ }^{12}$ Although these were only one tenth of the total, they accounted for about one fifth of the value. The biggest borrower in this category was Pedro Chanchorena who took out one loan for $\$ 4000$ and another for $\$ 1600$. Several others--Burucoa, Duralde, and Salaberry-took out loans for over $\$ 1000 .{ }^{13}$ There were, however, some modest loans for as little as $\$ 17$ to Miguel Videgain, a sheep herder. Although almost all the large nonHispanic borrowers appeared in the Census or in the voter registration records, none of the Hispanic borrowers except the sheep herder could be found. The big loans, suggestive of fairly large farmers, makes this absence surprising; and they may have been residents of another county.

Demand for labor on the expanding agricultural frontier was high, and the Chinese came to Ventura County in large numbers to work in the fields. A Chinatown grew up in Ventura, and some immigrants opened small businesses. Racial antipathy to the Chinese ran high in the American west in the late nineteenth century. An Anti-Chinese League was formed in Ventura in 1885 and a mass meeting was held at a union hall the following year. The league complained (Jennings, 1984) that " it is not fair that

${ }^{12}$ One other loan for $\$ 100$ had as a second borrower, Adolfo Camarillo.

${ }^{13}$ Levy's spelling of Spanish names was unconventional at times. 
white laboring men and women cannot gain employment instead of the Chinese." The Chinese community was subsequently intimidated by the police, and punitive taxes were levied on laundries. Dislike of the Chinese spilled over into the census. The census taker for Ventura Country was careless and hurried in recording the information on the Chinese population, making it impossible to distinguish names.

Local hostility to the Chinese did not prevent Levy from offering them some modest loans. Ha Kay Chang received a one-day $\$ 50$ loan at 2 percent quarterly, which he repaid in 70 days. Although this rate was fairly high, it appears that repayment may have eased subsequent terms. After Ah Gow wong obtained his first loan, a one-day $\$ 50$ loan at 2 percent quarterly, and repaid it in 108 days, he got a one-day $\$ 100$ loan at 1.5 percent quarterly, which was repaid in 59 days. While he still had this loan out, Wong borrowed another $\$ 100$ at the same rate for 88 days. Wong, a local farmer, borrowed even larger sums from the Bank of Hueneme, obtaining $\$ 2,000$ to $\$ 3,000$ on crop mortgages (Fairbanks (1963), Jennings, (1984)).

\section{Conclusion}

Although the Bank of $A$. Levy was modest even by the standards of country national banks, it was a well-developed commercial banking establishment by the turn of the nineteenth century. The bank fulfilled the financing needs of an expanding agricultural community and made loans to a broad cross section of the county. Loans were simple uncollateralized promissory notes that were made on the banker's judgment of the character and risk of the borrower. Loan rates varied considerably with the 
perceived reputation and risk of the borrower. Integrated into the money market, the loan portfolio was funded by the bank's capital, and a significant infusion of borrowed funds. Although the average or estimated aggregate loan rates were apparently high, the modal borrower obtained credit at 4 percent, a rate comparable with some of the best rates in the country. Nevertheless, the risky loans and the high rates paid on them enabled the bank to enjoy an overall high rate of return. 


\section{Bibliography}

A. Levy: A History (Virginia Beach, VA: The Donning Company Publishers), 1991.

"A. Levy, County Pioneer is Called," Moorpark Enterprise (February 23, 1922).

Adams, Donald R., Jr., "The Bank of Stephen Girard, 1812-1831," Journal of Economic History 22 (December 1972), pp. 841-68.

Bank of A. Levy, Notes and Bills Receivable (1892-1894), Notes and Bills Payable (1894-1904).

Battacharya Sudipto, and Anjan Thakor, " Contemporary Banking Theory," Journal of Financial Intermediation (October 1993), pp. $2-50$.

Board of Governors of the Federal Reserve System, Banking and Monetary statistics 1914-1941 (Washington, D.C.: Board of Governors of the Federal Reserve System, 1943).

Bodenhorn, Howard, "A More Perfect Union:Regional Interest Rates in the United States, 1880-1960," in Michael D. Bordo and Richard Sylla, Anglo-American Financial systems: Institutions and Markets in the Twentieth Century (New York: Irwin, 1995), pp. 415-454.

Bodenhorn, Howard, "Private Banking in Antebellum Virginia: Thomas Branch \& Sons of Peterburg," Business History Review 71 (Winter 1997), pp. 513-542.

Bodenhorn, Howard, "An Engine of Growth: Real Bills and Schumperterian Banking in Antebellum New York," Explorations in Economic History (July 1999), pp.

Bolles, Albert S., Practical Banking, 7th ed., (New York: Homans Publishing Company, 1884).

Brief, Richard P. "The Origin and Evolution of NineteenthCentury Asset Accounting," Business History Review 37 (Spring 1966), pp. 1-23.

Breckenridge, R. M., "Discount Rates in the United States," political Science Quarterly XIII (March 1898), PP. 119-142. 
Carroll, Russell, as told to Robert Pfeiler, "The Bank of A. Levy, Ventura County Historical Society Quarterly 4 (November 1958), pp. 10-13.

Crothers, A. Glenn, "Banks and Economic Development in PostRevolutionary Northern Virginia, 1790-1812," Business History Review 73 (Spring 1999), pp. 1-39.

Davis, Lance, "The Investment Market, 1870-1914: The Evolution of a National Market," Journal of Economic History XXV, 3 (September 1965). pp. 355-99.

Doti, Lynne Pierson, and Larry Schweikart, Banking in the American West: From the Gold Rush to Derequlation (Norman: University of Oklahoma Press, 1991).

Doti, Lynne Pierson, and Larry Schweikart, California Bankers, 1848-1993 (Ginn Press: Needham Heights, MA, 1994).

Fairbanks, F.L., "Early Day Banks and Banking in Ventura County," Ventura County Historical Society Quarterly 8. (May 1963), pp. 3-20.

Holmes, George K. and Lord, John S., Report on Real Estate Mortgages in the United States. Eleventh Census, Vol. XII (Washington D.C.: U.S. Government Printing office, 1895).

It's Been A Great 100 Years! Bank of A. Levy, 1882-1982 (Bank of A. Levy, 1982).

James, John, Money and Capital Markets in Postbellum America (Princeton: Princeton University Press, 1978).

Jennings, Margaret, "The Chinese in Ventura County," Ventura County Historical Society Quarterly 29 (Spring 1984), pp. 3-31.

Kramer, William M. and Norton B. Stern, "A. Levy of the Bank: From Beans to Banks in Ventura County," Western States Jewish Historical Quarterly VII, 2 (January 1975), pp. 118-137.

Lamoreaux, Naomi R., Insider Lending: Banks, Personal Connections and Economic Development in Industrial New England (New York: Cambridge University Press, 1994). 
Moulton, H.G., "Commercial Banking and Capital Formation," Journal of Political Economy, (May 1918, June 1918, July 1918, and November 1918).

Schweikart, Larry, A History of Banking in Arizona (Tuscon: University of Arizona Press, 1982).

U.S. Bureau of the Census. Eleventh Decennial Census of the United States, 1890: Vol I., Population. Part one. Vol. V., Report on the Satistics of Agriculture. Vol VI. , Report on Manufacturing, Part One. (Washington, D.C.: 1892-1897).

U.S. Bureau of the Census. Twelfth Decennial Census of the United States, 1900. Population Manuscript Census. Microfilm. Ventura county.

U.S. Comptroller of the Currency, Annual Report (Washington, D.C.: U.S. Government Printing Office, various years).

Ventura County. 1890 Great Register of Ventura County, California.

White, Eugene N., "Were Banks Special Intermediaries in Late Nineteenth Century America?" Federal Reserve Bank of St. Louis 80 (May/June 1998), pp. 13-32.

Wright, Robert E.," Bank Ownership and Lending Patterns in New York and Pennsylvania, 1781-1831," Business History Review 73 (Spring 1999), pp. 40-60. 
</ref_section> 